Proceedings

\title{
Evaluation of Extreme Dry and Wet Conditions Using Climate and Hydrological Indices in the Upper Part of the Gallikos River Basin ${ }^{+}$
}

\author{
Christos Mattas ${ }^{1, *}$, Christina Anagnostopoulou ${ }^{2}$, Panagiota Venetsanou ${ }^{1}$, Georgios Bilas ${ }^{3}$ and \\ Georgia Lazoglou ${ }^{2}$ \\ 1 Faculty of Science, School of Geology, Laboratory of Engineering Geology and Hydrogeology, \\ AUTH Thessaloniki 54124, Greece; pvenetsn@geo.auth.gr \\ 2 Faculty of Science, School of Geology, Department of Meteorology and Climatology, \\ AUTH Thessaloniki 54124, Greece; chanag@geo.auth.gr (C.A.); glazoglou@geo.auth.gr (G.L.) \\ 3 Faculty of Agriculture, Forestry and Natural Environment, School of Agriculture, Laboratory of Applied \\ Soil Science, AUTH Thessaloniki 54124, Greece; bilas@agro.auth.gr \\ * Correspondence: cmattas@geo.auth.gr, Tel.: +2310998519 \\ + Presented at the 3rd International Electronic Conference on Water Sciences, 15-30 November 2018; \\ Available online: https://ecws-3.sciforum.net.
}

Published: 15 November 2018

\begin{abstract}
Climate changes in the Mediterranean region, especially those related to changes in rainfall distribution and occurrence of extreme events, affect local economies. Agriculture is a sector strongly affected by climate conditions and concerns the majority of the Greek territory. The Gallikos river basin is an area of great interest regarding climate change impacts since it is an agricultural area depended on surface water resources and an area in which extreme events relatively often take place (e.g., floods). Long time series precipitation (27 years) and temperature data derived from measurement stations along with reanalysis data (ERA INTERIM) were used for the estimation of water availability and climate type over time in the area. The Standardized Precipitation Index and De Martonne aridity index was employed. The water flow measurements were correlated in order to investigate the interrelation between the different river branches and the extent of the meteorological changes effect in the basin. Descriptive statistics and cumulative curves were applied to check homogeneity of data. The results revealed that the climate type varies from semi arid to very wet, and water availability ranges from moderately dry to extremely wet years. Reanalysis data overestimate precipitation. The meteorological changes affect, at the same time, the entire basin since the flow rate peaks occur simultaneously in the hydrographic network at different areas.
\end{abstract}

Keywords: Gallikos; Standarized Precipitation Index; De Martonne Aridity Index; Floods

PACS: J0101

\section{Introduction}

The Intergovernmental Panel on Climate Change (IPCC) since 2008 has highlighted the vulnerability of freshwater resources against the observed climate change and pointed out the consequences to humans and ecosystems [1]. Climate change is a global phenomenon and many areas will be affected worldwide as well as in Europe [2]. The Mediterranean basin is considered to be one of the most prone areas to the impacts of climate change as it is mentioned by many researchers in their publications starting from previous decades $[3,4]$. The impacts of climate change 
on water resources, environment, and main economical sectors are critical issues that constitute a matter of concern for the Greek researchers [5-11]. In 2009, the Interdisciplinary Climate Change Impacts Study Committee was set (CCISC) up by the Bank of Greece for studying these impacts indicating the awareness of the Greek scientific society about climate change.

The climate of Greece is predominantly classified as Mediterranean [12], ranging locally to different climate types due to the geography, the extended coastlines, and the large number of islands. According to the Hellenic National Meteorological Service (HNMS), the main climate types that occur in Greece are Bsk, Bsh, Cfa, and Csa [13]. The first two aforementioned climate types correspond to semi arid types, and therefore, the areas belonging to these zones are suffering from long dry periods during the summer and are subjected to severe stress due to the agricultural and touristic activities. The spatial distribution of the climate in relation to water resources and crops has been investigated over the last decades using climate indices and relative thematic maps that depict the climate zonation for the Greek extent have been designed [14,15].

The Gallikos river basin is an agricultural area and a significant percentage of the residents are employed in this sector. The main crops are corn, tobacco, cotton, and sunflower that have high irrigation demands. Groundwater exploitation along the river banks is the main source in order to meet these demands. River is the main recharge source of the aquifers. Surface water abstractions for irrigation purposes take place by the construction of very small-scale dams or by direct abstractions. Extreme flooding events have been recorded over the last decades inundating large areas resulting in human losses, infrastructure, and agriculture damages [16]. The most recent events were recorded during the years 2004, 2014, and 2015. According to HNMS, the climate of the studied area is characterized as cold semi-arid (Bsk). Therefore, the Gallikos study area was selected as an indicative and representative case study for the investigation of the climate characteristics and its hydrological behavior under extreme conditions.

\section{Materials and Methods}

\subsection{Regional Setting}

The upper part of Gallikos river basin is located in northern Greece and has an extent of $868 \mathrm{~km}^{2}$. The river length within the boundaries of the study area is $45 \mathrm{~km}$. A very dense hydrographic network is developed in the area (see Figure 1). The water flow has a seasonal character [17]. The main geological formations that outcrop in the basin are Quaternary and Tertiary sediments, limestone, dolomites, and crystalline bedrock formations (gneiss, quartzites, schists) [18].

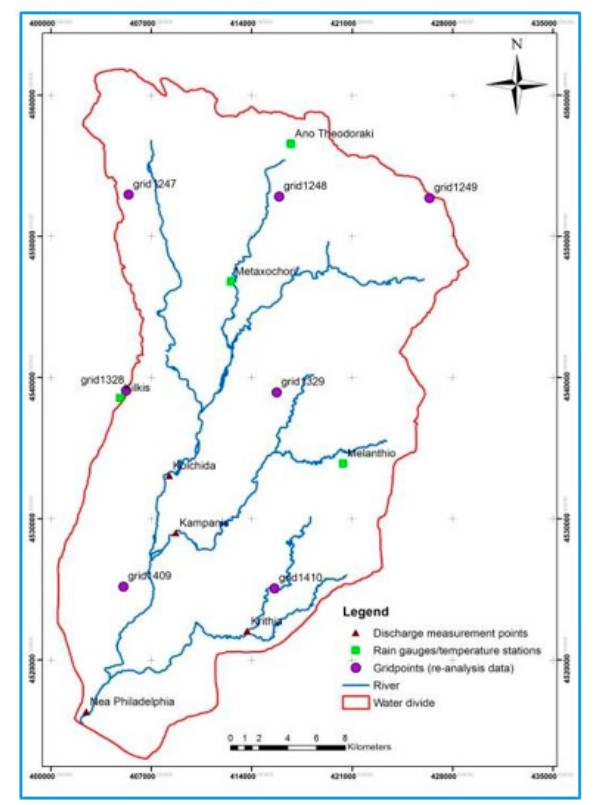

Figure 1. Map of the upper part of the Gallikos river basin. 


\subsection{Data Collection and Analysis}

Precipitation and temperature data were derived from reanalysis data base ERA-Interim (spatial resolution $12.5 \mathrm{~km} \times 12.5 \mathrm{~km}$ ) for the time period 1980-2006. Data from rain gauges and temperature measurement stations that were operating in the area for the same time period under the supervision of the competent authorities were also evaluated. During the years 2004 to 2006, the river water flow rate was measured at different major branches of the hydrographic network (see Figure 1) at specific time intervals and after rainfall events [19]. Descriptive statistics were applied on data. The Standarized Precipitation Index (SPI) and de Martonne Index was applied to investigate water availability and aridity of the studied region over the years.

SPI is a widely used index to characterize meteorological drought by quantifying precipitation deficit [20]. Depending on the SPI timescale range, drought impacts reflect the water availability on different water resources (e.g., soil moisture for short timescales, groundwater, and reservoir storage for long timescales). In the present paper, a 12 month timescale SPI was calculated for reanalysis and raw data.

The de Martonne aridity index is utilized as a measure of the aridity of an area at a local level [15]. Both annual and monthly values were calculated in the present study for reanalysis and raw data.

Annual cumulative curves are used in order to investigate the homogeneity of the measurements between the different rain gauges comparing each station with the others. The coincidence of the points on a straight line could mean that there is dependence between the rain gauges.

\section{Results}

The mean precipitation and temperature for the entire basin was estimated for the period 1980-2006. The results that are depicted in Table 1 showed that the reanalysis data overestimate the precipitation values, while the temperature values are quite similar. The homogeneity tests that were conducted between the data showed that all the measurements are quite reliable since the cumulative curves form straight lines with very high dependence.

In Figure 2 the river discharge fluctuation is depicted for the years 2004 to 2006 at four different locations (see Figure 1). The distribution of the values seems to follow a typical hydrological pattern for Greece. During summer months the lowest values are recorded. An increasing trend appears at the end of autumn along with precipitation increase and in winter (after January) that soil is saturated and the discharge has a continuous increase until the early summer months that starts to reduce as is expected. The curves that illustrate discharge are parallel. Peaks and low values occur at the same time. The different branches of the river are recharged mainly from rain (only a small number of springs with very small contribution to the river flow rate occur in the area) and drain distinct parts of the basin apart from Nea Philadelphia that is the receiver of the entire network discharge. The similarity of the fluctuation indicates, as a general rule, that the meteorological events (e.g., rainfall incidents or drought periods) affect the hydrographic network of the entire basin in the same way. 
Table 1. Mean annual precipitation and temperature for period 1980-2006 of the upper part of Gallikos basin.

\begin{tabular}{cc}
\hline \multicolumn{2}{c}{ Mean Annual } \\
\hline \multicolumn{2}{c}{ Precipitation $(\mathrm{mm})$} \\
\hline grid1409 & 603.90 \\
\hline grid1410 & 600.82 \\
\hline grid1328 & 609.44 \\
\hline grid 1329 & 608.2 \\
\hline grid1247 & 614.06 \\
\hline grid1248 & 618.08 \\
\hline grid1249 & 620.38 \\
\hline Re-analysis data & $\mathbf{6 1 0 . 7}$ \\
\hline Kilkis & 429.55 \\
\hline Ano Theodoraki & 442.91 \\
\hline Melanthio & 592.37 \\
\hline Metaxochori & 516.24 \\
\hline Raw data & 495.26 \\
\hline \multicolumn{2}{c}{ Temperature $\left({ }^{\circ} \mathrm{C}\right)$} \\
\hline grid1409 & 13.65 \\
\hline grid1410 & 13.79 \\
\hline grid1328 & 13.37 \\
\hline grid 1329 & 13.48 \\
\hline grid1247 & 12.98 \\
\hline grid1248 & 13.05 \\
\hline grid1249 & 13.11 \\
\hline Re-analysis data & $\mathbf{1 3 . 3 5}$ \\
\hline Ano Theodoraki & 13.37 \\
\hline Melanthio & 13.00 \\
\hline Metaxochori & 14.97 \\
\hline Raw data & $\mathbf{1 3 . 7 8}$ \\
\hline \\
\hline
\end{tabular}

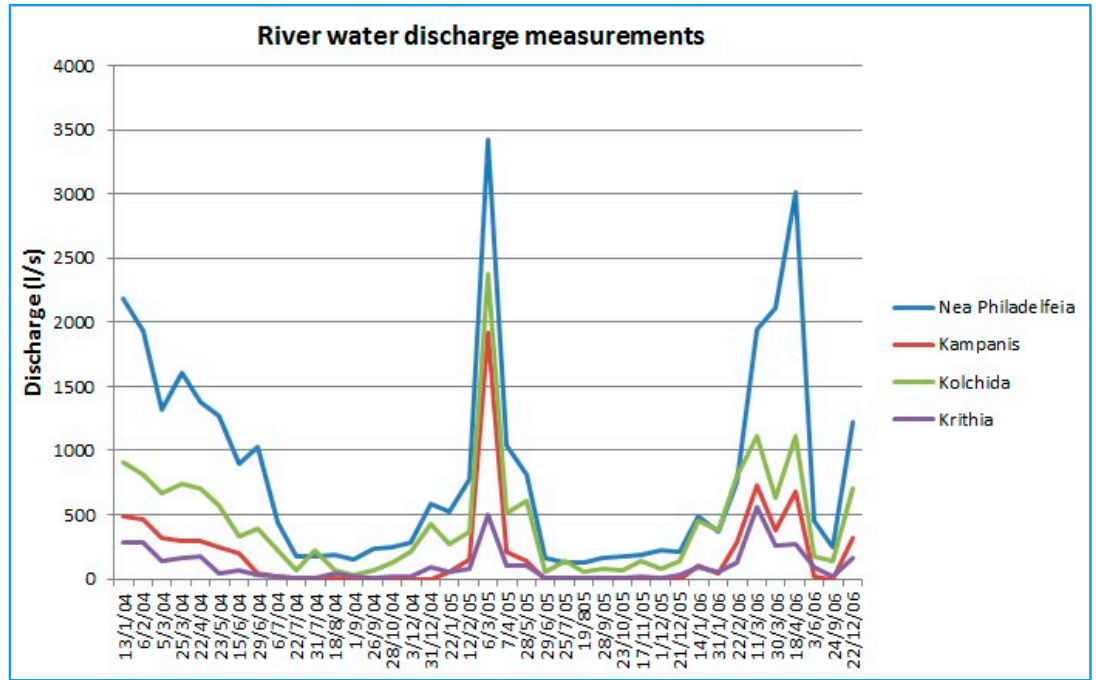

Figure 2. Fluctuation of discharge (2004-2006).

De Martonne aridity index for raw data showed a variation of the climate categories from semi dry to humid climates. More specifically for the 27 years, the climate percentages were: Semi dry $40.8 \%$, Mediterranean $25.9 \%$, semi humid $14.8 \%$, and humid $18.5 \%$. It is noticeable that five consecutive years (1990-1994) were recorded as semi dry period while the most humid period was 
between 2002-2006. The corresponding percentages for the reanalysis data were: Semi dry $7.4 \%$, Mediterranean $22.2 \%$, semi humid $25.9 \%$, humid $33.3 \%$, and very humid $11.2 \%$. These results suggest that the reanalysis data present much more wetter years compared to the raw data. According to the monthly de Martonne index of raw data for the time period 1980-2006, the land needs to be irrigated during the months June, July, August, and September.

The results of SPI index for a 12 month timescale for raw and reanalysis data are depicted in Figures 3 and 4, respectively.

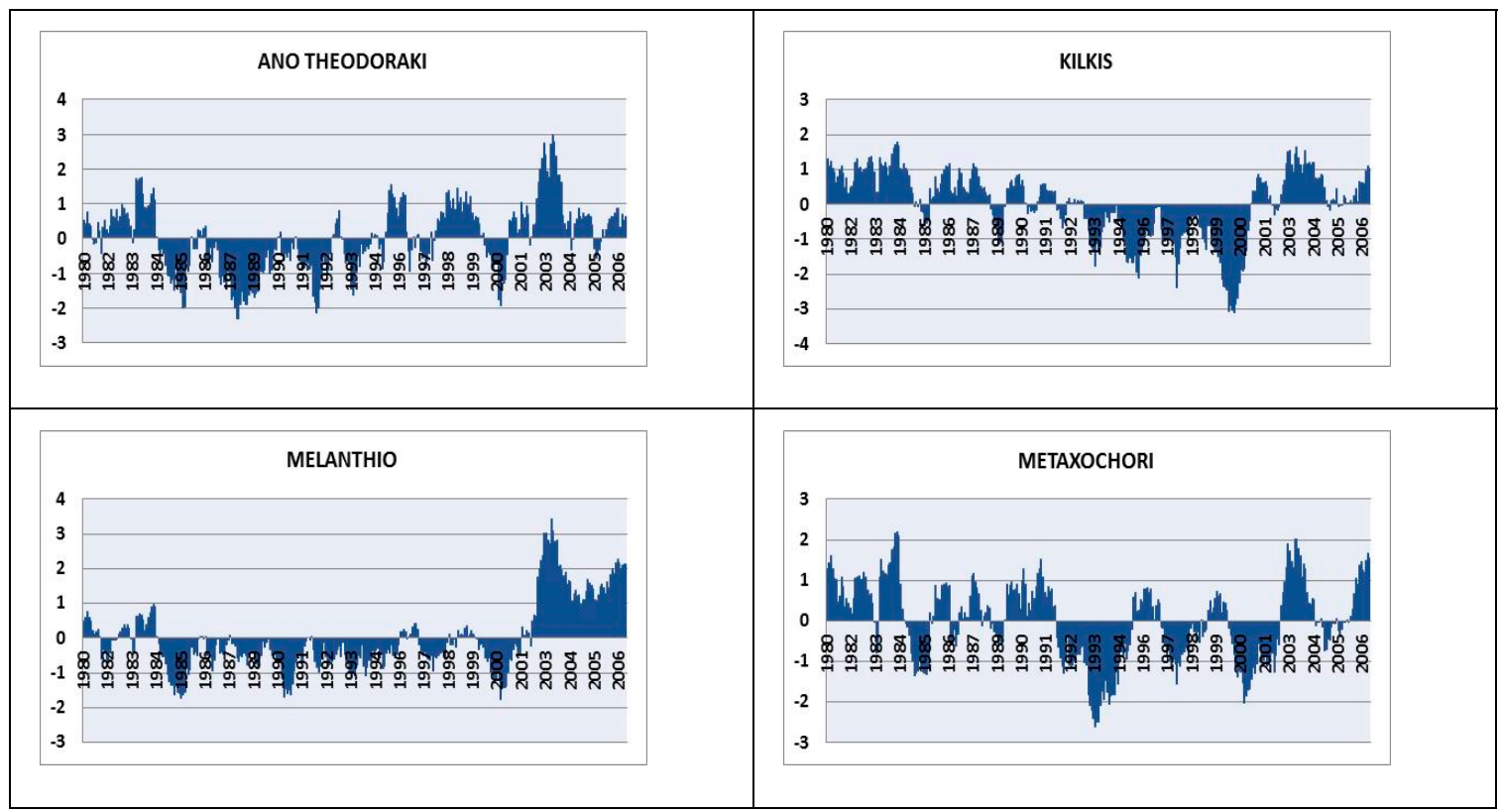

Figure 3. SPI -12 results for raw data.

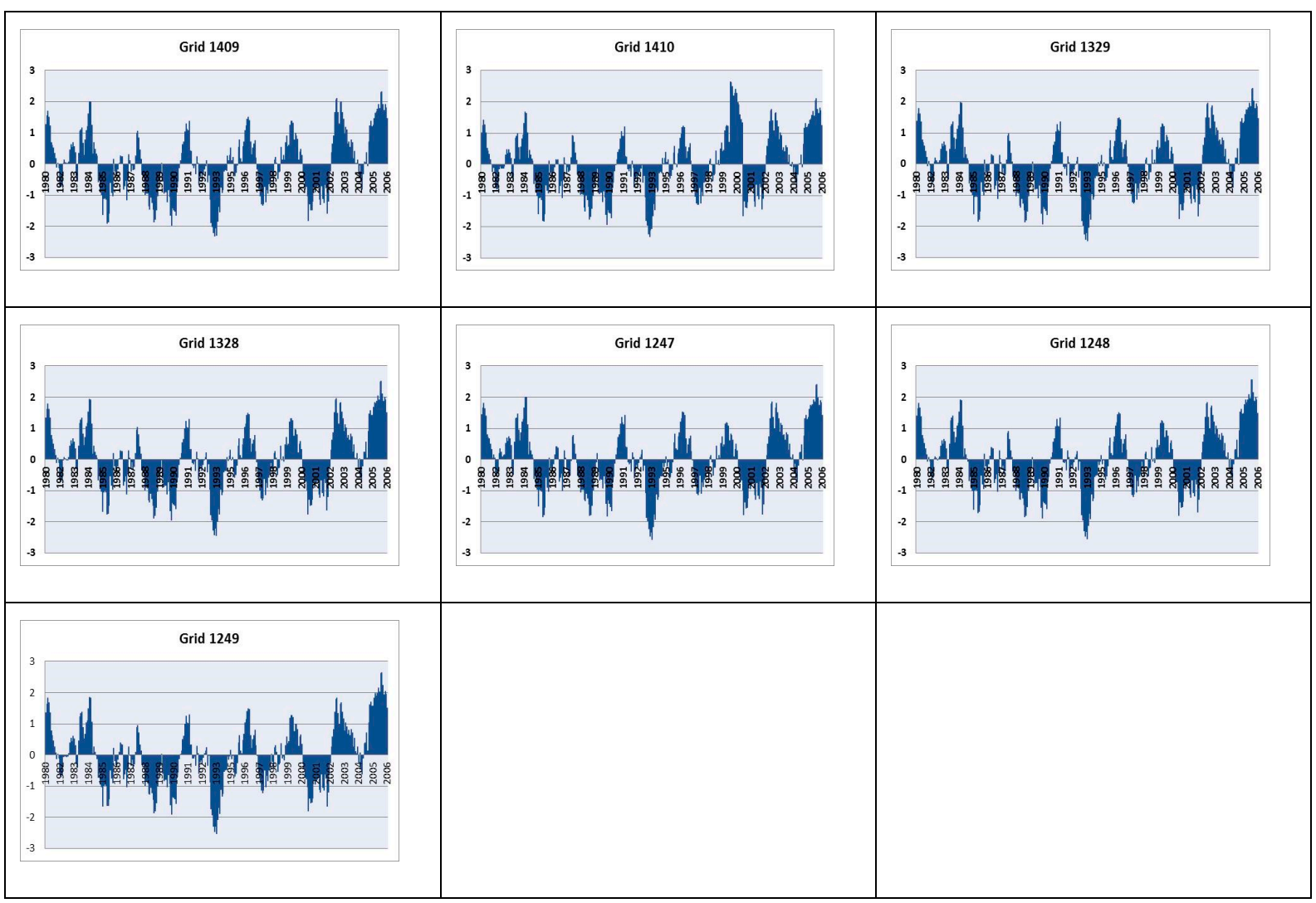

Figure 4. SPI -12 results for reanalysis data. 
As shown in Figure 3, there is a continuous change between wet and dry periods. The Melanthio rain gauge appeared to have the longest drought period, from 1984 to 2002, while for the Ano Theodoraki station, the dry period was from 1984 to 1995. The drought period for the Kilkis and Metaxochori stations was shifted to 1991 and 2001 showing a delay of approximately 10 years. The SPI values based on the reanalysis precipitation data are closer to the two Northern stations (Ano Theodoraki and Metaxochori). All grid points showed that the period 1991 to 1995 was the driest one, which is in accord with the De Martonne results.

\section{Discussion and Conclusions}

Water resources of Gallikos basin are under severe stress as is revealed by the application of SPI and de Martonne indices due to the long drought periods that can even last for decades. The agricultural sector is depended on water resources and therefore the economy of the area. The water resources managers that are involved in the area should act as soon as possible in order to prevent and reverse the existing and upcoming impacts from climate change and extreme conditions. An indicative set of measures could include change of cultivation types, construction of infrastructures for the exploitation of surface water (such as dams or implementation of artificial recharge), change of irrigation methods, and sufficient presence of the state control mechanisms.

Author Contributions: C.M. collected and evaluated the hydrological data and wrote the paper. C.A. conceived the idea and evaluated the climate data. P.V. and G.L. treated the climate data. G.B. enhanced the writing of the paper in collaboration with other authors.

Acknowledgments: Part of this work (for the upper part of Gallikos River basin) was elaborated in the framework of a research project funded by the Directorate General for Research and Technology (Greek Ministry of Development)

Conflicts of Interest: The authors declare no conflict of interest.

\section{Abbreviations}

The following abbreviations are used in this manuscript:

IPCC Intergovernmental Panel on Climate Change

CCISC Climate Change Impacts Study Committee

HNMS Hellenic National Meteorological Service

SPI Standarized Precipitation Index

\section{References}

1. IPCC. Climate Change and Water; IPCC Technical Paper VI; IPCC: Geneva, Switzerland, 2008.

2. European Commission. EU Action against Climate Change: Leading Global Action to 2020 and beyond, Environment; European Commission: Brussels, Belgium, 2008.

3. Lionello, P.; Malanotte-Rizzoli, P.; Boscolo, R.; Alpert, P.; Artale, V.; Li, L.; Luterbacher, J.; May, W.; Trigo, R.; Tsimplis, M.; et al. The Mediterranean climate: an overview of the main characteristics and issues. In Mediterranean Climate Variability; Lionello, P., Malanotte-Rizzoli, P., Boscolo, R., Eds.; Elsevier: Amsterdam, The Netherlands, 2006; pp. 1-26.

4. Lionello, P.; Scarascia, L. The relation between climate change in the Mediterranean region and global warming. Reg. Environ. Chang. 2018, 18, 1481, doi:10.1007/s10113-018-1290-1.

5. Georgopoulou E.; Mirasgedis S.; Sarafidis Y.; Vitaliotou M.; Lalas D.P.; Theloudis I.; Giannoulaki K-D.; Dimopoulos D.; Zavras V. Climate change impacts and adaptation options for the Greek agriculture in 2021-2050: A monetary assessment. Climate Risk Management, 2017, 16, 164-182.

6. Bank of Greece. The Environmental, Economic and Social Impacts of Climate Change in Greece. June 2011, Athens, ISBN: 978-960-7032-49-2 (in Greek). Available online: http://www.bankofgreece.gr/BogEkdoseis/Pkgqg1_Ejherg.pdf (accessed on 26 February 2019).

7. Giannakopoulos, C.; Kostopoulou, E.; Varotsos, K.V.; Tziotziou, K.; Plitharas, A. An integrated assessment of climate change impacts for Greece in the near future. Reg. Environ. Chang. 2011, 11, 829-843. 
8. $\quad$ Eleftheriou D.; Kiachidis K.; Kalmintzis G.; Kalea A.; Bantasis C.; Koumadoraki P.; Spathara M.E.; Tsolaki A.; Tzampazidou M.I, Gemitzi A. Determination of annual and seasonal daytime and nightime trends of MODIS LST over Greece - climate change implications. Sci. Total Environ. 2018, 616-617, 937-947.

9. Koutroulis A.G.; Tsanis I.K.; Daliakopoulos I.N.; Jacob D. Impact of climate change on water resources status: A case study for Crete Island, Greece. J. Hydrol. 2013, 479, 146-158.

10. Mimikou, M.; Baltas, E. Assessment of Climate Change Impacts in Greece: A General Overview. Am. J. Clim. Chang. 2013, 2, 46-56, doi:10.4236/ajcc.2013.21005.

11. Arampatzis G.; Panagopoulos A.; Pisinaras V.; Tziritis E.; Wendland F. Identifying potential effects of climate change on the development of water resources in Pinios River Basin, Central Greece. Appl. Water Sci. 2018, 8, 51, doi:10.1007/s13201-018-0690-1.

12. Peel, M.C.; Finlayson, B.L.; McMahon, T.A. Updated world map of the Köppen-Geiger climate classification. Hydrol. Earth Syst. Sci. 2007, 11, 1633-1644.

13. Kottek, M.; Grieser, J.; Beck, C.; Rudolf, B.; Rubel, F. World map of the Köppen-Geiger climate classification updated. Meteorologische Zeitschrift 2006, 15, 259-263, doi:10.1127/0941-2948/2006/0130.

14. Anagnostopoulou, C. Drought episodes over Greece as simulated by dynamical and statistical downscaling approaches. Theor. Appl. Climatol. 2017, doi:10.1007/s00704-016-1799-5

15. Baltas, E.A. Climatic Conditions and Availability of Water Resources in Greece. Int. J. Water Resour. Dev. 2008, 24, 635-649, doi:10.1080/07900620802230129.

16. Tsitroulis, I.; Voudouris, K.; Vasileiou, A.; Mattas, C.; Sapountzis, M.; Maris, F. Flood hazard assessment and delimitation of the likely flood hazard zones of the upper part in Gallikos river basin. Bull. Geol. Soc. Greece 2016, 50, 995-1005, doi:10.12681/bgsg.11804.

17. FRA Report. Implementation of the European directive 2007/60/EC. Preliminary assessment of the flood hazard. Athens, December 2012, p. 122 in Greek. Available online: http://www.ypeka.gr/LinkClick.aspx?fileticket=T4DDG1hqQMY\%3d\&tabid=252\&language=elGR (accessed on 26 February 2019).

18. Mattas, C.; Voudouris, K.S.; Panagopoulos. A. Integrated Groundwater Resources Management Using the DPSIR Approach in a GIS Environment Context: A Case Study from the Gallikos River Basin, North Greece. Water 2014, 6, 1043-1068.

19. Mattas, C. Hydrogeological Research of the Gallikos River Basin. Ph.D. Thesis, School of Geology, AUTH, Thessaloniki, Greece, 2009.

20. World Meteorological Organization. Standardized Precipitation Index User Guide; WMO-No. 1090; Svoboda, M., Hayes, M., Wood, D., Eds.; World Meteorological Organization: Geneva, Switzerland, 2012. 